\title{
Comunication/Comunicação
}

\section{Fauna of Culicidae in rural areas of Porto Velho and the first record of Mansonia (Mansonia) flaveola (Coquillet, 1906), for the State of Rondônia, Brazil}

\author{
Fauna de Culicidae em áreas rurais de Porto Velho e primeiro registro de Mansonia (Mansonia) \\ flaveola (Coquillet, 1906), para o Estado de Rondônia, Brasil
}

\section{Renata Antonaci Gama1, Ivoneide Maria da Silva ${ }^{2}$, Hamilton Antônio de Oliveira Monteiro ${ }^{3}$ and Álvaro Eduardo Eiras ${ }^{4}$}

\begin{abstract}
Introduction: Knowledge concerning the fauna of Culicidae in the Brazilian Amazon States contributes to current understanding of the bionomics of the insects collected and makes it possible to observe changes in the fauna over time. Methods: The Culicidae were captured with a BG-Sentinel® trap in extra-domiciliary area of two rural regions of Porto Velho in June and July of 2007 and 2008. Results: A total of 10,695 Culicidae was collected, belonging to nine genera: Coquillettidia, Culex, Mansonia, Psorophora, Aedes, Aedeomyia, Anopheles, Uranotaenia and Wyeomyia. Conclusions: The presence of Mansonia (Mansonia) flaveola was recorded in the State of Rondônia for the first time.
\end{abstract}

Keywords: Culicidae. Mansonia flaveola. BG-Sentinel trap ${ }^{\circledR}$. Anopheles.

\section{RESUMO}

Introdução: $\mathrm{O}$ conhecimento da fauna de culicídeos em estados da Amazônia Brasileira auxilia no conhecimento da bionomia dos insetos obtidos, além de possibilitar a observação de modificações da fauna ao decorrer do tempo. Métodos: As capturas dos culicídeos foram realizadas em área extradomiciliar de duas zonas rurais de Porto Velho, durante junho e julho, nos anos de 2007 e 2008, com a armadilha BG-Sentinel ${ }^{\circledR}$. Resultados: Foram coletados 10.695 culicídeos, distribuídos em nove gêneros: Coquillettidia, Culex, Mansonia, Psorophora, Aedes, Aedeomyia, Anopheles, Uranotaenia e Wyeomyia. Conclusões: Foi registrada pela primeira vez no estado a presença de Mansonia (Mansonia) flaveola.

Palavras-chaves: Culicinae. Mansoniaflaveola. BG-Sentinel trap®. Anopheles.

The Amazon is the biome with the greatest entomological diversity in Brazil and the study of its fauna is very relevant. The entomofauna of the State of Rondônia is poorly documented, particularly with respect to the Culicinae population. Culicidae studies conducted in Rondônia include those by Xavier \& Mattos ${ }^{1}$ in Guajará Mirim and Porto Velho, Klein et $\mathrm{al}^{2}$ in Costa Marques, Luz \& Lourenço de Oliveira $^{3}$ in Candeias do Jamari and Cruz et $\mathrm{al}^{4}$ in Porto Velho. The aim of this study was to contribute to the knowledge concerning the fauna of Culicidae in rural areas of Porto Velho, State of Rondônia.

1. Laboratório de Insetos e Vetores, Centro de Biociências, Universidade Federa do Rio Grande do Norte, Natal, RN. 2. Laboratório de Parasitologia Médica, Instituto de Ciências Biológicas, Universidade Federal do Pará, Belém, PA. 3. Seção de Arbovirologia e Febres Hemorrágicas, Instituto Evandro Chagas, Secretaria de Vigilância em Saúde, Ministério da Saúde, Ananindeua, PA. 4. Laboratório de Ecologia Química de Insetos Vetores, Instituto de Ciências Biológicas, Universidade Federal de Minas Gerais, Belo Horizonte, MG.

Address to: Dra. Renata Antonaci Gama. Lab. Insetos e Vetores/CB/UFRN. Av. Salgado Filho 3000, Candelária, 5906-6800 Natal, RN, Brasil.

Phone: 5584 9607-0119

e-mail: antonaci@cb.ufrn.br

Received in 29/06/2010

Accepted in 14/01/2011
The collections were made in two locations of Porto Velho, Mato Grosso ( $8^{\circ} 44^{\prime} 09$ 40”S, 6356'07 40”W) and São João (8 49'55 $09^{\prime \prime}$, 63056'15 15”W). The first collection point was on BR 364 near kilometre 9.5, and the second on BR 319 at kilometre 1 after Rio Madeira, in the direction of Humaitá, State of Amazonas. The collections in Mato Grosso were made during the months of June and July 2007 and in São João, in the same months in 2008. The two locations were within large forested areas, near water bodies. The approximate distance between the two areas was $9 \mathrm{~km}$.

The samples were collected in extra-domiciliary environments, $15 \mathrm{~m}$ from the residence, over a period of $2 \mathrm{~h}$ ( $6 \mathrm{pm}$ to $8 \mathrm{pm})$ using BG-Sentinel ${ }^{\circledR}$ traps $^{5}$. Dry ice was used as a $\mathrm{CO}_{2}$ source. The samples were identified using dichotomous keys ${ }^{6,7}$. Mosquito species diversity in Mato Grosso and São João was evaluated by using the Shannon diversity index $\left(\mathrm{H}^{\prime}\right)$.

Voucher specimens were deposited in the entomologylaboratory of the Federal University of Rio Grande do Norte and in the Department of Arbovirology of the Evandro Chagas Institute.

In the two selected locations 10,695 Culicidae were collected; only $1.5 \%$ of the specimens were male. Out of the nine collected genera (Coquillettidia, Culex, Mansonia, Psorophora, Aedes, Aedeomyia, Anopheles, Uranotaenia and Wyeomyia), 15 species were identified (Table 1), of which Coquillettidia and Anopheles had the highest occurrence, 44.9 and $20.7 \%$, respectively.

The least represented genus was Uranotaenia, with only two collected specimens, one from each year (Table 1). On average, 77.5 Culicidae were collected per hour. Only 130 specimens could not be identified at least by genus due to poor specimen conditions. The genera and species collected in the two locations were similar, although the genus Wyeomyia was only captured in São João and the Shannon diversity indices were different: São João was H' 0.8847 and Mato Grosso was H’0.5560.

The genera with the highest number of species were Mansonia and Anopheles.

During studies on human bait in rural areas in Porto Velho, Cruz et a $1^{4}$ collected a total of 3,121 mosquitoes from eight different genera and the most common genera were Mansonia (47.9\%), Anopheles (27.6\%), Coquillettidia (12.4\%), Culex (8.4\%) and Psorophora (3.5\%). Luz \& Lourenço de Oliveira ${ }^{3}$ collected a total of 3,769 mosquitoes in Candeias do Jamari (RO), on human bait. Of the nine collected genera, 21 species were identified and the members of the genus Aedes were the most common Culicidae. 
TABLE 1 - Culicidae collected from Mato Grosso and São João, two rural locations in Porto Velho, State of Rondônia, in June and July 2007 and 2008, respectively, using a BG-Sentinel trap ${ }^{\circledR}$.

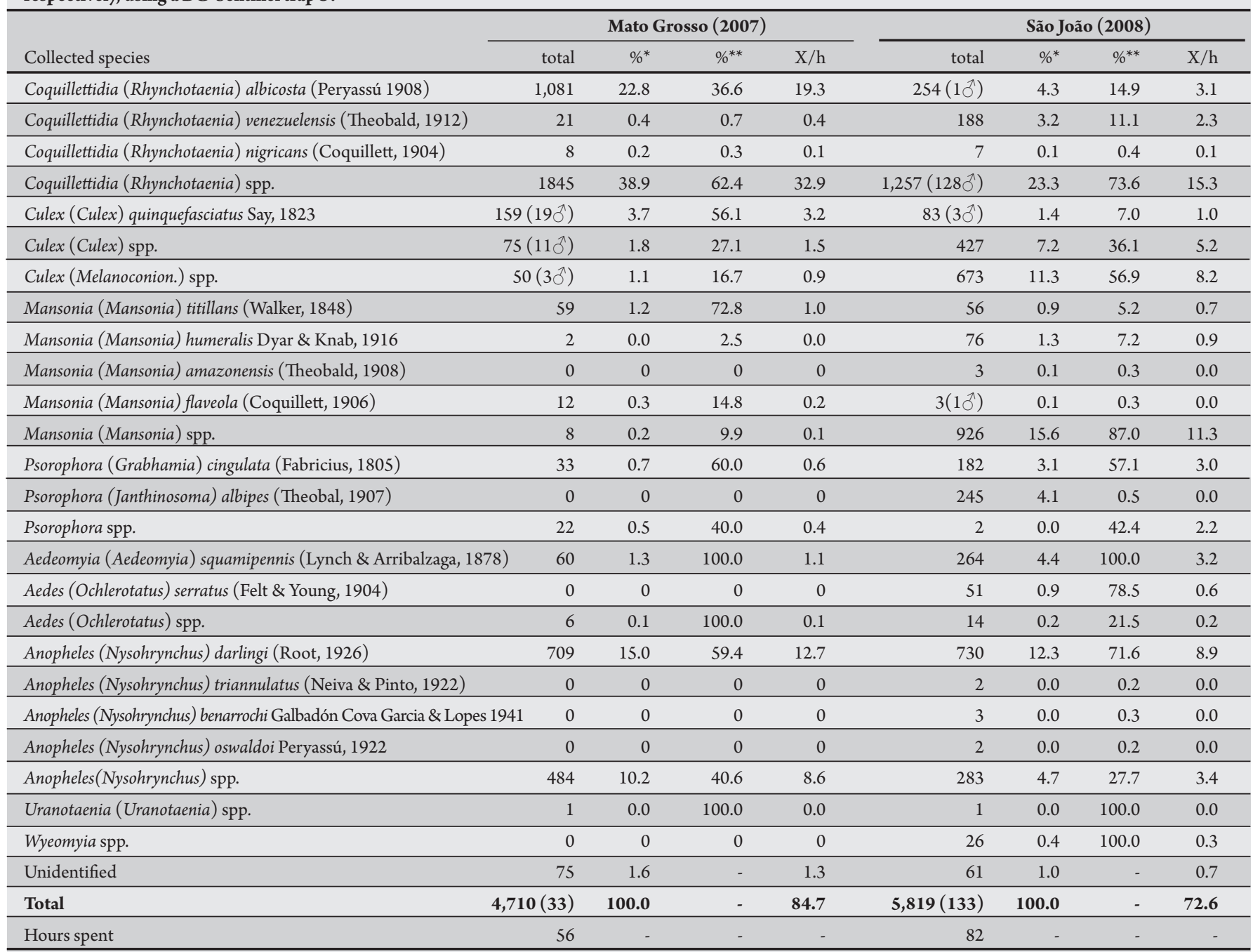

${ }^{*}$ In relation to the total Culicidae, ${ }^{* *}$ In relation only to the genus, $\mathrm{X} / \mathrm{h}$ : average Culicidae per hour.

In the present study, 15 mosquito species were collected in Porto Velho, 9 of which have been incriminated in disease transmission to humans, mostly arboviroses and malaria. Some species were found naturally infected with arbovirus: Aedeomyia squamipenis (Gamboa), Anopheles triannulatus (Arumateua, Caraipe, Tacaiuma), Aedes serratus (Aura, Caraparu, Venezuelan equine encephalitis virus, Guama, Ilheus, Mirim, Mucambo, Oriboca, Oropouche, Una), Coquillettidia venezuelensis (Bussuquara, Catu, Guama, Itaporanga, Moju, Mucambo, Oriboca, Oropouche), Culex quinquefasciatus (West Nile Virus, Oropouche, St. Louis encephalitis virus) and Psorophora albipes (Yellow fever virus, Venezuelan equine encephalitis virus, Guama, Itheus, Kairi, Mayaro, Una) $)^{8,9}$.

Among the 2,213 anophelines, four different species were identified: Anopheles darlingi (65\%) was present in Mato Grosso and São João, while A. triannulatus, A. benarrochi and Anopheles oswaldoi together comprised $0.3 \%$. Three of the anopheline species collected are important in the transmission of malaria: $A$. darling $i$ is considered to be one of the most efficient malaria vectors in the Neotropical region ${ }^{10}$; A. triannulatus was found naturally infected with Plasmodium, including in Rondônia ${ }^{11}$ and A. oswaldoi has been confirmed as a malaria vector in Brazil, Peru, Colombia and Venezuela ${ }^{10}$.
In a study realized in four rural areas in Porto Velho (Mato Grosso, Nova Esperança, São João and Candeias do Jamari) on human bait, $\mathrm{Gama}^{12}$ collected a total of 985 anophelines. Among these 972 were A. darlingi. The others species were: Anopheles mediopunctatus/ costai/forattini (2), A. triannulatus (7), A. benarrochi (1), Anopheles nuneztovari (1) and Anopheles braziliensis (2).

Eighty percent of the territory of the State of Rondonia is covered by the Amazon forest. Of the studies of its Culicidae fauna, the majority involve the subfamily Anophelinae due to the high transmission of malaria in the state. Few projects have investigated local Culicinae and most used traps to capture the mosquitoes, which damages the specimens, as occurred in this project.

Compared to previous studies performed in the State of Rondônia, only the genera Orthopodomyia, Sabethes, Trichoprosopom ${ }^{1,3}$, Limatus and Rhunchomyia ${ }^{1}$ were not identified in this study.

With the exception of the species M. (M.) flaveola, all of the genera and species presently collected in Mato Grosso and São João had already been reported in the State of Rondônia. Mansonia (Mansonia) flaveola was first described in 1906 by Coquillett as Taeniorhynchus flaveolus, and renamed in 1970 by Belkin, Heinemam 
\& Page 1970. It is found in North America (though only in Florida in the US), Central America (the Virgin Islands, Jamaica, Puerto Rico, Panama) and South America (Suriname, French Guyana, Peru, Bolivia, Argentina, and Brazil, specifically Amazonas, São Paulo and Paraná) ${ }^{13}$. Mansonia (Mansonia) flaveola is easy to identify due to its characteristic maxillary palpus (about half as long as the proboscis) and yellow-coloured scutum. The biology of M. flaveola is similar to that of other species of the genus, presenting nocturnal behaviour, voracious and aggressive females and activity peak at dusk.

The scarce literature on Culicinae in the State of Rondônia and the fact that some of the species identified in this study are considered significant etiological vectors justifies similar studies in other areas of the state, especially using techniques that better preserve specimens and permit the collection of male specimens to study their genitalia. Although the study was conducted in the dry season (only two months in each location) and some specimens could not be identified at least by genus due to poor specimen conditions, the results demonstrate that the BG-Sentinel trap ${ }^{\circledR}$ is an efficient sampling method for the adult female Culicidae.

\section{ACKNOWLEDGMENTS}

The authors would like to thank LACEN Rondônia employees for logistical support and Biogents for supplying the BG-Sentinel traps ${ }^{\circledR}$.

\section{CONFLICT OF INTEREST}

The authors declare that there is no conflict of interest.

\section{FINANCIAL SUPPORT}

This work was supported to the Ministry of Health and Pan American Health Organization-OPAS, CNPq and CAPES (scholarships).

\section{REFERENCES}

1. Xavier SH, Mattos SS. Lista das espécies e gêneros de culicídeos encontrados nos Estados do Brasil. VIII. Rondônia (Diptera, Culicidae). Acta Amaz 1989; 19:285-294.

2. Klein TA, Lima JBP, Tang AT. Seasonal distribution and diel biting patterns of culicine mosquitoes in Costa Marques, Rondônia, Brazil. Mem Inst Oswaldo Cruz 1992; 87:141-148.

3. Luz SLB, Lourenço de Oliveira R. Forest Culicinae mosquitoes in the environs of Samuel Hydroeletric Plant, State of Rondônia, Brazil. Mem Inst Oswaldo Cruz 1996; 91:427-432.

4. Cruz RMB, Gil LHS, Silva AA, Araújo AS, Katsuragawa TH. Mosquito abundance and behavior in the influence area of the hydroelectric complex on the Madeira River, Western Amazon, Brazil. Trans R Soc Trop Med Hyg 2009; 103:1174-1176.

5. Kroeckel U, Rose A, Eiras AE, Geier M. New tools for surveillance of adult yellow fever mosquitoes: comparasion of trap catches with human landing rates in an urban environment. J Am Mosq Control Assoc 2006; 22:229-238.

6. Forattini OP. Culicidologia Médica, Volume 2: Identificação, biologia e epidemiologia. São Paulo: EDUSP; 2002.

7. Consoli RAGB, Lourenço de Oliveira R. Principais mosquitos de importância sanitária no Brasil. Rio de Janeiro: Editora FIOCRUZ; 1994.

8. Segura MN, Castro FC. Atlas de Culicideos na Amazônia Brasileira: Características especificas de insetos hematófagos da família Culicidae. Ananindeua: Instituto Evandro Chagas. Ministério da Saúde. Secretaria de Vigilância em Saúde; 2007.

9. Degallier N, Travassos da Rosa APA, Vasconcelos PFC, Hervé JP, Sá Filho G, Travassos da Rosa JFS, et al. Modifications of arbovírus transmission in relation to construction of damas in Brazilian Amazônia. J Braz Assoc Adv of Science 1992; 44:125-135.

10. Sinka ME, Palis YR, Manguin S, Patil AP, Temperley WH, Gething PW, et al The dominant Anopheles vectors of human malaria in the Americas: ocurrence data, distribution maps and bionomics précis. Parasites \& Vectors 2010; 3:72.

11. Deane LM. Malaria vectors in Brazil. Mem Inst Oswaldo Cruz 1986; 81:5-14.

12. Gama RA, Santos RLC, Santos F, Silva IM, Resende MC, Eiras AE. Periodicidade de captura de Anopheles darlingi Root (Diptera: Culicidae) em Porto Velho, RO. Neotropical Entomol 2009; 38:677-682.

13. Barbosa AA. Revisão do subgênero Mansonia Blanchard, 1901 (Diptera: Culicidae) e estudo filogenético de Mansoniini. [Tese de doutorado]. [Curituba (PR)]. Universidade Federal do Paraná; 2007. 158 p. 